IZA DP No. 5644

Consistency in Organization (updated)

Ekkehart Schlicht

April 2011 


\title{
Consistency in Organization (updated)
}

\author{
Ekkehart Schlicht \\ University of Munich \\ and IZA
}

\section{Discussion Paper No. 5644 \\ April 2011}

\author{
IZA \\ P.O. Box 7240 \\ 53072 Bonn \\ Germany
}

Phone: +49-228-3894-0

Fax: +49-228-3894-180

E-mail: iza@iza.org

Any opinions expressed here are those of the author(s) and not those of IZA. Research published in this series may include views on policy, but the institute itself takes no institutional policy positions.

The Institute for the Study of Labor (IZA) in Bonn is a local and virtual international research center and a place of communication between science, politics and business. IZA is an independent nonprofit organization supported by Deutsche Post Foundation. The center is associated with the University of Bonn and offers a stimulating research environment through its international network, workshops and conferences, data service, project support, research visits and doctoral program. IZA engages in (i) original and internationally competitive research in all fields of labor economics, (ii) development of policy concepts, and (iii) dissemination of research results and concepts to the interested public.

IZA Discussion Papers often represent preliminary work and are circulated to encourage discussion. Citation of such a paper should account for its provisional character. A revised version may be available directly from the author. 


\section{ABSTRACT}

\section{Consistency in Organization (updated) ${ }^{*}$}

Internal organization relies heavily on psychological consistency requirements. This thought has been emphasized in modern compensation theory, but has not been extended to organization theory. The perspective sheds new light on several topics in the theory of the firm, like the boundaries of the firm, the importance of fairness concerns within firms, the attenuation of incentives, or the role of routines and incentives. It implies a perceptional theory of the firm that is realistic in the sense advocated by Ronald Coase (1937).

\section{NON-TECHNICAL SUMMARY}

The paper develops the idea that the organization of a firm's internal activity relies on psychological consistency requirements. As a consequence, fairness considerations are of paramount importance, and the limits of the firm are determined by the requirements of a coherent corporate culture.

JEL Classification: B52, D02, L2

Keywords: theory of the firm, hierarchy, evolutionary theory of the firm, perceptional theory of the firm, consistency, small numbers, centralization paradox, Williamson's puzzle, compensation, boundaries of the firm, fairness, idiosyncratic exchange, entitlements, obligations, routines, framing, Simon, employment relationship, fairness, ownership effect, skunkworks, disruptive technologies, Tayloristic organization, holistic organization

Corresponding author:

Ekkehart Schlicht

Institutional Economics Group

Department of Economics

University of Munich

Schackstr. 4

80539 Munich

Germany

E-mail: schlicht@Imu.de

\footnotetext{
* This is a revised update of Schlicht $(2003,2008)$. As compared to the earlier IZA Discussion Paper No. 718 of 2003, the present version includes a number of small changes and improvements, some remarks on the efficiency-enabling aspects of fairness that builds on Herbert Simon's (1951) theory of the employment relationship, and a note the phenomenon of skunkworks that lend further support to the theory of the firm suggested here.
} 
1 Small Numbers - 2 Markets, Hierarchies, and Custom - 3 Entitlements, Obligations, and Organizational Equilibrium - 4 Consistency - 5 The Boundaries of the Firm - 6 The Perceptional Theory of the Firm - 7 Low-Powered Incentives -

8 Fairness as a Precondition for Profit Seeking - 9 Routines and Change -

10 Concluding Remarks

\section{Small Numbers}

Coordination in a well-matched team is typically characterized by specialization of the team members and the absence of relevant competition for each specialist. In such a setting, market coordination seems less useful. It would invite strategic behavior, and would necessitate protective measures to shield against such tactics. Each team member could threaten to block the gains from cooperation unless paid a larger share of the surplus. The potential conflicts and concomitant safeguards involve sunk costs, to be counted as transaction costs. Such transaction costs are quite different from - and more important than - the costs "of discovering what the relevant prices are," as there are many ways of splitting any surplus, and there is no clear-cut way for "discovering" any set of relevant prices. The costs for settling disputes may be considerable in any small-number setting unless organizational features and firm-specific norms are implemented that reduce higgling and haggling.

Organizational features and firm-specific norms may curb rent-seeking activity by ruling out some alternatives or rendering them more costly to pursue. A policy, for example, that requires equal treatment of all employees according to certain principles restrains the individual worker from seeking an exception, because all concessions made to him will generalize to other workers. This renders it more costly for the firm to make such concessions, and less promising for the individual worker to request them. As a result, rent-seeking activity and associated transaction costs are reduced, and the employment relationship becomes more efficient ex ante as well as ex post. We can expect organizational solutions to outcompete market solutions in such cases. ${ }^{1}$ More generally, coordination within firms pertains to well-matched teams that entail, almost by definition, small-number problems, and firms that rely on nonmarket organization may

1 Similar constraints on bargaining may arise in markets as well, but will, as a rule, be less powerful and are disregarded in the following in order to simplify the exposition. 
obtain better results than the market could achieve. As a consequence, prices are rarely used within firms to coordinate the division of labor. Even if payments serve as incentives, they do not perform any market-clearing function. ${ }^{2}$

\section{Markets, Hierarchies, and Custom}

Behavior within an organization is motivated and controlled differently from what occurs in the market. Psychological consistency molds behavior and is of central importance for internal organization. But before developing this thought, let us consider briefly a position that denies the theoretical usefulness of distinguishing between markets and firms in terms of different modes of motivation and control. According to this view, all behavior, whether occurring in the market or within firms, is governed by incentives, and a firm is to be interpreted as a specialized market, rather than a categorically different organizational form. ${ }^{3}$ As Alchian and Demsetz explain: "Telling an employee to type this letter rather than to file that document is like my telling a grocer to sell me this brand of tuna rather than that brand of bread." ${ }^{4}$ According to this view, no useful analytical distinction can be drawn between command and free choice, even if people in real life happen to make such a distinction. People do not change their nature when entering a firm. Whether inside or outside a firm, their behavior is controlled by the same behavioral tendencies. If they behave differently within the firm or in the marketplace, this is to be attributed to the different sets of incentives provided. Human behavior is always to be analyzed in terms of (given) preferences and constraints. I shall refer to this view as the the principal-agent view of the firm, and I am going to criticize it.

I accept the thesis that people do not change their nature when entering a firm, but I take them as norm-guided to much larger extent within firms

\footnotetext{
2 Schlicht $(1998,229 f f$.

3 Holmstrom (1982)

4 Alchian and Demsetz (1972, 277)
} 
than in the market. ${ }^{5}$ It is not only incentives and constraints that determine behavior; rather perceptions of entitlements and obligation influence action as well, and firms use normative structures that create entitlements and obligations for purposes of internal coordination that are absent or strongly attenuated in markets, and this enables them to outperform markets.

Many writers have rejected the principal-agent view of the firm, often implicitly. Ronald Coase is outspoken, however. He draws a distinction between a principal-agent relationship and a master-servant relationship and cites Batt: "... that which distinguishes an agent from a servant is not the absence or presence of a fixed wage, or the payment only of commission on business done, but rather the freedom with which an agent may carry out his employment." 6 From this he concludes that the employment contract differs from a principal-agent relationship. It is a "master-servant" relationship, involving "control" and "direction." I take it that "control" and "direction" refer to normatively supported ways of affecting behavior.

Herbert Simon reiterated the point that the employment contract establishes an authority relation, and Oliver Williamson followed his lead, in effect taking up Marx's distinction between the social division of labor in the market and the division of labor in manufacture. ${ }^{7}$ Simon drew a distinction between markets and hierarchies and pointed out that the market will select that mode of coordination that minimizes overall production costs - a view which I am going to accept in this paper.

The dichotomy between markets and hierarchies found in Marx, Coase, Simon, and Williamson is to be complemented by taking account of duty and custom. Harvey Leibenstein has highlighted this when depicting the firm as a network of interrelated jobs. Each job is associated with duties and responsibilities, entitlements and obligations. The organization of work is achieved, in his view, by the way in which appropriate norms, attached to jobs, govern behavior. ${ }^{8}$

\footnotetext{
5 The view advanced here builds in part on Isaac et al. (1991), who emphasize that institutions (and therefore firms) frame fairness perceptions that entail strong behavioral effects. See also Schlicht (1998) for further discussion.

6 Coase $(1937,404)$, Batt $(1929,6)$

7 Simon (1951), Williamson (1985), Marx (1867, xv.4).

8 Leibenstein (1965)
} 
A closely related argument has been invoked by Nelson and Winter. They start, like Williamson, with the observation that the market does not work well in settings of idiosyncratic exchange. There may initially be a quarrel among the team members for obtaining larger shares of the surplus at the expense of the others, but eventually a "truce" will emerge, which is maintained and defended by everybody because "each member strives to protect his interests by standing prepared to deliver a firm rebuff not only to actions by others that clearly threaten his interests, but also to actions that might be quite innocuous were it not for their possible interpretation as probes of his alertness or determination to defend his rights under a truce". ${ }^{9}$ For such reasons, everybody defends the firm-specific norms and customs even in cases where he is not personally affected.

\section{Entitlements, Obligations, and Organizational Equilibrium}

The above discussion can be developed as follows. In a first step, an organization could be interpreted as a set of conventions. But why do people obey these conventions? One answer would be to think of a set of self-sustaining conventions that everybody obeys because it is in everybody's interest to follow these conventions provided everybody else does the same. ${ }^{10}$ This view may be adequate for dealing with pure coordination problems, like driving on the right-hand side of the road. It is the easy case and does not involve any problem. Such a system would work automatically, and there would be no further need for governance, and hardly any need for a firm as we know it.

The small-number problems arising in teams give rise, however, to coordination problems of a different kind. They require a splitting of the surplus accruing from cooperation. They involve potential conflict. An organization must cope with these problems. A convention to split a surplus according to a certain rule cannot easily be self-enforcing, because some team members may be first movers. They could try to increase their share in the surplus, knowing that it would be rational for the others to accommodate this step. The threat to

9 Nelson and Winter $(1982,111)$

${ }^{10}$ Kreps (1990) 
cease cooperating would be irrational for the later movers. In other words, the idea of viewing an organization as a set of conventions that are maintained out of self-interest of the participants seems very problematic.

Yet evidence suggests that people actually do behave "irrationally" if they feel cheated. They try to defend what they perceive as their entitlements, even if this involves substantial costs to them. Effective norms are defended in this manner. Strategic behavior is channeled by these firm-specific norms. If the firm adheres to principles of equal treatment of equals, for example, a worker will anticipate that any concession made to him will induce other workers to seek the same advantage. Hence he will rather look for fostering his own advantage within the given set of norms and principles. This channels his activity. Improvements in governance, in the sense of implementing better norms, can induce better performance.

Further, effective norms shape compliance. They induce entitlements and obligations. Entitlements are rights, as perceived by the individuals. They are not, however, abstract legal rights. Rather, they denote the subjectively perceived rights that go along with a motivational disposition to defend them. Obligations are the counterparts of entitlements. They refer to claims by others that are subjectively accepted by the individual, and go along with a motivational disposition to respect these claims. ${ }^{11}$ Both entitlements and obligations are brought about by a set of established rules. They derive from regularities perceived in the past and in the group, and they bring about norms and customs. Governance can be improved by establishing regularities that give rise to appropriate entitlements and obligations. ${ }^{12}$

Given a set of norms and customs within a firm, and a preparedness of the members to defend the entailed entitlements and honor the implied obligations, it may be tempting to view behavior in analogy to the simple coordination problem, but on a higher level. Conforming to firm-specific norms may be construed as individually rational if everybody expects everybody else to defend these conventions. However, the behavioral effect of such rules cannot

11 Schlicht $(1998,24)$.

12 Some condemn such thoughts as involving manipulation of the employees, and interfering with their free choices. See Schlicht (2004) for a discussion of this issue. 
be reduced to incentives. Rather, the rules generate incentives because they elicit entitlements and obligations and induce behaviors that will mutually be taken into account. The resulting organizational equilibrium, as governed by entitlements and obligations, may be viewed as a "truce," as Nelson and Winter have proposed. It seems to me, however, that this parlance wrongly invokes the idea that organizational equilibrium is built on latent conflict. ${ }^{13}$ It wrongly suggests that mutual entitlements and obligations are only obeyed because they are backed up by threats. This is a misleading way of looking at organizational equilibrium, because truce is usually short-lived, both within organizations and between nations, and prone to transform either into peace or into war after a while. It seems thus more appropriate to describe organizational equilibrium as peace, where conflicts have settled down and a possible initial truce has engendered a mutually accepted arrangement that is defended by everybody, similar to the way in which hierarchies or territorial claims are defended after settlement.

An analogy can be found in the way in which pecking orders and territoriality are established among animals. Consider the establishment of a pecking order among hens. There may be initial fights, but after a while a pecking order is established and only rarely put into question. The hens generalize apparently from the outcome of one fight to the outcome of the next one and avoid unnecessary fighting. Or consider territoriality. There may be an initial fight, and the stronger individual might occupy a certain territory. It will defend its territory and will chase away potential intruders, but once the territorial boundaries are established real fights will be rare. The ownership effect will induce the owner of a territory to win almost any fight - even against stronger intruders. It has obtained, so to speak, an entitlement in the territory, which induces it to defend it more fiercely than it would fight as an intruder, and the intruders' aggressiveness is muted by the partial recognition of the territorial rights of the owner. ${ }^{14}$ In this way, ownership generates preferences, as well as incentives. Regarding preferences, it renders the owner more aggressive and

\footnotetext{
${ }_{13}$ This applies to the radical theory of the firm as well; see (Marglin, 1974). Oliver Williamson (1980) has commented on that.

${ }^{14}$ See the discussion and references in Schlicht (1998, 11-115, 172-175). Biologists describe the ownership effect as rendering the owner more aggressive than the intruder; see Maynard Smith (1978).
} 
the intruder more yielding. As both the owner and the intruder will take this effect into account, this changes their incentives for maintaining the territory, or invading it. The tendency is strengthened among social animals by the way in which the members of a group maintain or change alliances, and a similar social amplification must be expected within any social organization. ${ }^{15}$

\section{Consistency}

Yet a firm's internal organization is not fully reducible to routines, norms, and firm-specific customs. The element of command - emphasized rightly by Coase and Williamson - is of great importance as well, but simply adding hierarchy and command to routines, norms, and firm-specific customs will not suffice to compleat the picture, as all elements interact strongly, and monetary incentives play a role as well. In the remaining part of the paper I shall comment on the nature of this interaction. ${ }^{16}$

My main thesis is that the actual working of an organization depends strongly on aspects of psychological consistency. The term refers to an overall match between various organizational features, principles, and tacit understandings. It plays an important part in modern compensation theory, but has much broader significance with regard to organizational matters. ${ }^{17}$ It bundles command, incentives, and custom together and implies a strong interaction between command, firm-specific norms, and incentives.

Consider the starting point of Coase's discussion of the employment relationship. He notes correctly: "If a workman moves from department $Y$ to department $X$, he does not go because of a change in relative prices, but because he is ordered to do so." ${ }^{18}$ The foreman is well advised, however, not to issue arbitrary orders, even if they remain within the limits set by the employment

\footnotetext{
${ }^{15}$ See De Waal (1983) on the importance of forming alliances in groups of chimpanzees, and Dunbar and Schutz (2007) for the "social brain" thesis.

${ }^{16}$ See also Schlicht $(1998,227-233)$, where the interaction of monetary incentives, custom, and command is interpreted as "chemical interaction" in the sense of Mill (2004, iii.x.4).

${ }^{17}$ Milkovich and Newman (1999), Baron and Kreps (1999).

${ }^{18}$ Coase $(1937,378)$
} 
contract. He must be entitled to order the workman to move, and it will be his duty not to issue inappropriate orders. The authority of the foreman and the obedience of the worker will be hurt if the foreman gives incoherent orders. The consistency of his behavior is tied up with his competence, as perceived by his subordinates, which is an important element in eliciting authority. He must, for instance, issue similar orders under similar circumstances.

If the worker in department $Y$ is idle each afternoon, but helpful in department $X$, the foreman will be bound to send the workman each afternoon to department $X$. After a while, such an order will appear redundant. The workman will know and go by himself, and he might fear reprisal if he does not help in department $X$ in the afternoon even if not explicitly ordered to do so. He will begin to see this as his duty.

Authority is in this way tied up with job roles and responsibilities. Every order and every decision creates a precedent. It molds entitlements and obligations and strengthens or weakens authority. As a consequence, every order and decision must be seen as both directing resources and shaping firm-specific customs. While a command entered into the keyboard of a computer may be issued without affecting the response of the computer to other commands, this does not hold true within a firm. Within a firm, however, every command creates the expectation that similar future situations will be handled in a similar manner, and weakens behaviors that appear inconsistent with the command. Each command creates entitlements and obligations. It induces generalization. This is of obvious productive advantage in so far as it automatizes certain adaptations, but may be of disadvantage in case some generalizations are unwarranted. ${ }^{19}$

\footnotetext{
${ }^{19}$ In this sense, Walsh (2010) distinguishes between "coercive command" that is based on threats, and "command as an articulation of rules that have been voluntarily committed to." While large segments of economic writings emphasize the first meaning, he argues that command within firms usually takes the latter form. It is seen as rule-based and ultimately grounded in situation-specific requirements; see also Follett $(1940,59)$ and Brady and Walsh (2008).
} 


\section{The Boundaries of the Firm}

Oliver Williamson has emphasized the "chronic puzzle" about the limits of the firm. ${ }^{20}$ Two firms $A$ and $B$ can do together whatever they could do separately and more. There is thus no inefficiency to be expected if firms $A$ and $B$ integrate; we could rather expect some efficiency gains achievable by selective intervention. The puzzle is that we do not find firms getting larger and larger. Sometimes it is successful to downsize or split. It must, therefore, sometimes be cheaper to organize the sets of activities of $A$ and $B$ separately than jointly. As Williamson put it, "the integrated firm cannot wholly replicate outside procurement in 'business as usual' respects. Instead, there are unavoidable side effects." 21

The aspect of consistency contributes to understanding some of these unavoidable side effects: While firms $A$ and $B$ can each develop a specialized set of customs that are fine-tuned to their particular needs, firm $A B$ cannot handle similar things differently in its departments $A$ and $B$. That would hurt consistency. It may still be possible to differentiate between departments, but in many cases (such as compensation policies) this is very difficult and costly to sustain. It is a frequent occurrence that certain activities are outsourced for the simple reason of making it possible to pay the outsourced workers differently from what they would receive as regular employees. Janitors are outsourced in order to save on wage payments; computer specialists are outsourced in order to make it possible to pay them more. ${ }^{22}$ It is also common practice to hive off the development of new products in skunkworks, with the explicit intention to remove the constraints that would be unavoidable if the project would be carried through within the firm. ${ }^{23}$ It has been even suggested that some highly successful innovations have been left unexploited or handed over to other firms because pursuing them would have created problems within the existing firm organization. ${ }^{24}$ In these cases, the consistency requirement works as a constraint,

\footnotetext{
${ }^{20}$ Williamson $(1985$, Ch. 6). This is also known as Stiglitz' $(1991,18)$ "centralization paradox."

${ }^{21}$ Williamson $(1985,138)$

22 See Mücke (2002) for some illustrations.

${ }^{23}$ Bower and Christensen (1995), Bommer et al. (2000), Leitl (2006).

${ }^{24}$ Walsh $(2008,142)$.
} 
and disintegration may permit removing it. Conversely, integration induces the consistency constraint as an unavoidable side effect.

\section{The Perceptional Theory of the Firm}

I have interpreted the firm as an organizational unit that relies on norms and customs for coordination, rather than on market incentives. For such a system to work, the boundaries of the firm must be recognizable for its members, because they must know whether the firm-specific norms are valid or not. This implies a perceptional theory of the firm: The firm is what the firm members perceive as a firm. This perception frames and thereby triggers their behavior. Or, in the terminology of Isaac, Mathieu and Zajac, firms and other institutions provide institutional frames that activate certain behaviors rather than others. ${ }^{25}$

From this point of view, the boundaries of the firm relate to perceptional boundaries: A firm is what people identify as a firm. This notion of the firm is realistic, in the sense advocated by Coase: It "closely approximates the firm as it is considered in the real world." 26 The relevance of the "perceptional," or "realistic," notion of the firm derives from the fact that people base their actions on their perceptions. This renders their perceptions economically relevant.

If a theorist argues that the perceptional view of the firm is too fuzzy and vague, and a more clear-cut definition, such as the firm as a "nexus of contracts," or the firm as a "collection of assets," is analytically more convenient or fruitful, they must assume a priori that the notion of the firm entertained by the economic subjects themselves does not carry behavioral implications. ${ }^{27}$ In contrast, the consistency argument advanced here emphasizes the behavioral entailment of perceptions, and implies that the notion of the firm would actually be superfluous if it did not carry such behavioral implications.

\footnotetext{
${ }^{25}$ Isaac et al. (1991)

${ }^{26}$ Coase $(1937,404)$

${ }^{27}$ Jensen and Meckling (1976), Moore (1992)
} 


\section{Low-Powered Incentives}

Williamson has contrasted the prevalence of low-powered incentives within firms with the high-powered incentives prevalent in markets. ${ }^{28}$ While no $a$ priori reason can be given for firms not to deviate from markets in the other direction and offer super-powered incentives, several reasons for the attenuation of incentives within firms have been advanced. The consistency view adds some further arguments for attenuation.

According to the consistency view, firms rely on norm-guided behavior. The set of entitlements and obligations that regulates cooperation cannot be mixed easily with incentives, because the provision of incentives changes entitlements and obligations. Once a worker receives performance pay, this removes his obligation to work fast on order. The presence of performance pay creates the entitlement on the part of the worker to choose his own pace of work, and weakens or removes his obligation to work as he is told. ${ }^{29}$ The theoretical argument relates to the theory of self-attribution. ${ }^{30}$ It suggests, for instance, that incentives may reduce cooperation, and this has been confirmed experimentally. ${ }^{31}$ As firms must rely on norm-guided cooperation, and wage compression and an attenuation of incentives may improve the workings of duty of command, such features are to be expected.

\section{Fairness as a Precondition for Profit Seeking}

The thought that norm-guided behavior is important within firms may also be rephrased in a different way by building on Herbert Simon's theory of the

\footnotetext{
${ }^{28}$ Williamson $(1985,140)$

${ }^{29}$ This thought may help to understand the difference between incentives and command and may contribute to resolve Clark's(1984) puzzle that incentives that must be considered optimal from a principal-agent perspective were replaced by authority in many capital-intensive factories in the late nineteenth century. Only if authority works differently from incentives do these findings make sense.

30 Schlicht (1998, Ch. 9)

${ }^{31}$ Brown et al. 2002, Fehr and Gächter (2002)
} 
employment relationship. ${ }^{32}$ Consider two different tasks, $A$ and $B$. Assume initially that the worker is indifferent about whether to perform the one or the other. An exchange contract would specify under which conditions the worker would perform which. An employment contract would leave that unspecified. The firm would be free to decide, according to the situation, which task the worker is to perform. As long as the worker is indifferent between the tasks, he will be indifferent between the exchange contract and an employment contract. The firm, however, will prefer the employment contract, as this permits postponing the decision about which task to perform. It permits greater flexibility. The employment contract carries an option value, just as the holding of money rather than some illiquid asset entails liquidity. This is, in a nutshell, Simon's explanation of the employment contract.

Consider now the case that the the worker is not indifferent between tasks $A$ and $B$ but prefers task $A$. An employment contract faces the difficulty that the worker may be hesitant to agree on entering a contract that leaves the choice between $A$ and $B$ entirely in the hands of the firm, as he may fear of becoming exploited by being ordered to work exclusively on the dreary task $B$. In order to render an employment contract viable, the firm must credibly commit itself to compensate the worker for additional toil. By offering extra payment for task $B$ (working at night, working abroad), the worker can be made indifferent between the tasks, and the employment contract can serve the function of postponing the decision about performing task $A$ or task $B$.

From this point of view it it is no coincidence that businessmen talk about "compensation" rather than "pay." Practitioners aim for a consistent wage structure that offers rewards in proportion to the time needed to perform a task, and to the strain and attention required, rather than to bribe workers to perform the one rather than the other task. The latter would undermine the possibility of directing workers by command.

Another way to maintain the viability of the employment contract in cases where workers are not indifferent between performing different tasks is to implement practices that fix the shares of the various tasks while maintaining the flexibility of timing - in our example, maintaining the shares of tasks $A$ and

32 Simon (1951) 
$B$ while leaving it to the firm's discretion when to ask the worker to perform task $A$ or task $B$, respectively. A worker who has been assigned to the strenuous task $B$ for some time would obtain the "right" to be compensated by being assigned preferentially to task $A$ for a while, etc. This would, again, make the workers ultimately indifferent between performing the different tasks. Such practices relate obviously to fair treatment of the workers. The observation of fairness requirements turns out to be a fundamental prerequisite for rendering the employment contract viable and enabling its superior efficiency features. Rather than posing a constraint on profit seeking, as Kahneman, Knetsch, and Thaler see it, fairness turns out to be a precondition for profit seeking. ${ }^{33}$

Lindbeck and Snower (2000) have observed a recent tendency away from "Tayloristic" to "holistic" forms of the organization of work within firms and argue that multitasking, job rotation, and demands on the versatility of labor become increasingly important. According to the perspective developed here, such a development would demand the removal of incentives that hinder such holistic organization, and fairness as an enabler of efficient coordination will become even more essential in the future than it is to-day. ${ }^{34}$

Further, fairness in the employment contract - in the sense of offering compensation for more arduous tasks, in one way or another - contributes not only to the efficiency of the firm, but also to social efficiency, as compensating wage differentials bring about product prices that correctly reflect the cost of labor used for producing the various products.

\footnotetext{
${ }^{33}$ Kahneman et al. (1986)

${ }^{34}$ In contrast, Lindbeck and Snower $(2001,1854)$ speculate regarding holistic work organization: "Under multi-tasking, wages have a dual role: they influence both the number of people employed and their time allocations across tasks" and conclude from that that this would require differentiated and unequal treatment of workers and tasks. This position, although widely adopted, seems untenable. As Ludsteck (2003) has pointed out, differentiated pay for different tasks requires that the tasks can be observed. Hence the "time allocation across tasks" can be controlled directly by command, and it is not necessary to provide different wages for different tasks and individuals to induce the required time allocation, as Lindbeck and Snower assume. More generally speaking, Lindbeck and Snower follow the principal-agent view and assume that the wage structure and the command structure are substitutes for purposes of directing labor, while the position developed here maintains that any command structure requires an appropriate wage structure that enables the command mechanism.
} 
All this is quite remote from concerns about those kinds of incentives that are in the focus of the principal-agent paradigm. Such incentives may play a role in cases where observability is a problem. Within firms this seems to be less important, as you cannot compensate or incentivize what you cannot observe. You can, however, render the performance of tasks more attractive by offering performance pay, especially in cases where problems of observability do not arise. It is therefore not surprising that incentives are usually framed as a fair share in the value that has been created by the worker to the benefit of the firm. Such payments are much smaller than principal-agent theory would predict. ${ }^{35}$ Well-known phenomena like the attenuation of incentives, wage compression, or selection wages would not be observed if the principal-agent view of the employment contract were correct.

To phrase these thoughts in still another way: Within markets, prices coordinate various economic activities. Within firms, coordination is achieved by the assignment of duties and responsibilities, by direct control and supervision, and by supplementing all this with fair and consistent compensation structures. These mechanisms of coordination within firms are rendered viable by virtue of normative structures that ultimately build on perceptions of fairness and legitimacy and are shaped in the past and incessantly remolded by the daily operations and interactions taking place within the firm.

\section{Routines and Change}

The evolutionary theory of the firm emphasizes the function of routines to coordinate the division of labor within firms. The emphasis on routines, although in many ways quite relevant, hides the fact that the various routines to be found in a firm are tied together by consistency requirements. Similar cases must be treated similarly. Otherwise, entitlements and obligations will not match, and coordination cannot work smoothly. Further, the evolutionary view tends to conceive change as brought about by blind trial and error. This is misleading. Ronald Coase has pointed this out nicely: "The firm, the market, the legal system are all social institutions and are the result of purposeful human activity.

${ }^{35}$ Frank (1984) 
... natural selection has an IQ of zero. The IQ of businessmen and politicians may not be high, but it is not zero. Natural selection produces its results by trial and error over long periods of time. Economic systems, such as the structure of an industry, may be transformed within a single generation." ${ }^{36}$ Economic change is neither blind nor fully rational.

It seems to me that this "intermediate" character of economic change neither blind nor prescient - can be analyzed fruitfully from a consistency perspective. Firms respond to changing conditions by changing or enlarging their repertoire of action, and they seek improvements by building on their competencies. All this must be done in a piecemeal way and using the means at hand while maintaining overall consistency, even in times of change. The firm is not reshaped optimally in response to each and every change in the environment; rather, the existing routines are kept, or modified, or extended, and aligned with each other. ${ }^{37}$ It would not be "rational" to start anew at each point in time; rather it is reasonable to respond to new exigencies, or find new solutions, by starting from the prevailing set of routines, norms and customs, and by extending and changing them to meet new exigencies. As the prevailing set of routines is tied together by consistency requirements, organizational change is channeled by these requirements, just as biological change is channeled by physical and genetic conditions. ${ }^{38}$

\section{Concluding Remarks}

The consistency view of organization highlights some often neglected aspects of organizational performance. It requires transcending the standard assumptions on human behavior used in economics, as epitomized by the principal-agent view.

\footnotetext{
${ }^{36}$ Coase $(1978,244)$

37 Alchian $(1984,47)$ denies that when taking the principal-agent view to the extreme and concludes: "It is not silly to consider the entry of a new stockholder to be the creation of a new firm." This neglects the costs of setting up a system of rules that coordinate interaction. Once this is taken into account, any change (like the entry of a new stockholder) must be integrated into the existing set of routines, customs, and firm-specific norms, rather than creating a new firm from scratch.

${ }^{38}$ Schlicht (1997)
} 
Tastes and constraints are not the only determinants of behavior. Rather the perception of a situation affects attitudes, preferences, and perceived constraints. All this contributes in shaping behavior. The above discussion was intended to introduce this thought and to relate it to some selected topics in the theory of the firm. What has been left out here is a more detailed examination of possible empirical predictions and a more systematic discussion of the underlying model of man.

\section{Acknowledgment}

The first version of this paper has been presented on the occasion of Oliver Williamson's 70th birthday in Berkeley in 2002. I thank an anonymous referee of the Journal of Institutional and Theoretical Economics for suggestions and insightful comments on an earlier draft. Comments by Aidan Walsh have been helpful for providing this version.

\section{References}

Alchian, A. A. (1984). Specificity, Specialization, and Coalitions. Journal of Institutional and Theoretical Economics, 140: 34-39. URL http://www.digizeitschriften. de/main/dms/img/?PPN=GDZPPN001798537.

Alchian, A. A., and Demsetz, H. (1972). Production, Information Costs, and Economic Organization. American Economic Review, 62: 777-95. URL http://econpapers.repec.org/RePEc:aea:aecrev:v:62:y:1972:i:5:p:777-95.

Baron, J. N., and Kreps, D. (1999). Strategic Human Resources. New York: Wiley. URL http://amazon.com/o/ASIN/0471072532/.

Batt, F. A. (1929). The Law of Master and Servant. London: Pitman and Sons. URL http://amazon.com/o/ASIN/B0000CNJVO/.

Bommer, M., DeLaPorte, R., and Higgins, J. (2000). Project Management Skunkworks: Breaking the Rules. Discussion paper, IAMOT Paper Archive. URL http://www.iamot.org/paperarchive/102B.PDF. 
Bower, J. L., and Christensen, C. M. (1995). Disruptive Technologies: Catching the Wave. Harvard Business Review, 73(1): 43-53. uRL http://apps.business. ualberta.ca/mlounsbury/techcom/readings/disruptivetechnologies.pdf.

Brady, M., and Walsh, A. (2008). Setting Strategic Direction: A Top Down or Bottom Up Process? Business Strategy Series, 9(1): 6-11. URL http: //dx.doi.org/10.1108/17515630810850064.

Brown, M., Falk, A., and Fehr, E. (2002). Contractual Incompleteness and the Nature of Market Interactions. IEW - Working Papers 38, Institute for Empirical Research in Economics - IEW, Institute for Empirical Research in Economics, University of Zurich, Blümlisalpstrasse 10, CH-8006 Zürich. URL http://econpapers.repec.org/RePEc:zur:iewwpx:038.

Clark, G. (1984). Authority and Efficiency. The Labor Market and the Managerial Revolutionof the Late Nineteenth Century. Journal of Economic History, 44(4): 1069-83. uRL http://econpapers.repec.org/RePEc:cup:jechis:v:44:y:1984:i: 04:p:1069-1083_03.

Coase, R. H. (1937). The Nature of the Firm. Economica, 4: 386-405. URL www.jstor.org/stable/pdfplus/2626876.pdf.

Coase, R. H. (1978). Economics and Biology: Evolution, Selection, and the Economic Principle:Discussion. American Economic Review, 68(2): 244-5. URL www.jstor.org/stable/pdfplus/1816697.pdf.

De Waal, F. (1983). Chimpanzee Politics: Power and Sex Among Apes. New York: HarperCollins. URL http://amazon.com/o/ASIN/0801863368/.

Dunbar, R. I. M., and Schutz, S. (2007). Evolution of the Social Brain. Science, 317: 1344-1347. uRL http://psych.mcmaster.ca/psyweb/3f3e/reading2.pdf.

Fehr, E., and Gächter, S. (2002). Do Incentive Contracts Crowd Out Voluntary Cooperation? Discussion paper 34, Institute for Empirical Research in Economics, University of Zürich. URL http://econpapers.repec.org/paper/zuriewwpx/ 034.htm. 
Follett, M. P. (1940). Dynamic Administration. The Collected Papers of Mary Parker Follett. New York: Harper and Brothers. URL http://amazon.com/o/ASIN/ 0415279852/.

Frank, R. H. (1984). Are Workers Paid their Marginal Product? American Economic Review, 74(1): 549-71. URL http://econpapers.repec.org/RePEc:aea: aecrev:v:74:y:1984:i:4:p:549-71.

Holmstrom, B. (1982). Moral Hazard in Teams. Bell Journal of Economics, 13(2): 324-40. URL http://econpapers.repec.org/RePEc:rje:bellje:v:13:y:1982:i:autumn:p: $324-340$.

Isaac, R. M., Mathieu, D., and Zajac, E. E. (1991). Institutional Framing and Perceptions of Fairness. Constitutional Political Economy, 2(3): 329-70. URL http://www.springerlink.com/content/w0k82j060275396t/.

Jensen, M. C., and Meckling, W. (1976). Theory of the Firm: Managerial Behavior, Agency Costs, and Ownership Structure. Journal of Financial Economics, 3: 305-60. URL http://econpapers.repec.org/RePEc:eee:ffinec:v:3:y: 1976:i:4:p:305-360.

Kahneman, D., Knetsch, J., and Thaler, R. H. (1986). Fairness as a Constraint on Profit Seeking: Entitlements in the Market. American Economic Review, 76(4): 728-41. URL http://econpapers.repec.org/RePEc:aea:aecrev:v:76:y:1986:i:4: p:728-41.

Kreps, D. M. (1990). Corporate Culture and Economic Theory. In J. E. Alt, and K. A. Shepsle (Eds.), Perspectives on Positive Political Economy. Cambridge: Cambridge University Press. URL http://amazon.com/o/ASIN/0521398517/.

Leibenstein, H. (1965). Economic Theory and Organizational Analysis. Harper \& Row, reprint edition. ISBN 9780063562622. URL http://amazon.com/o/ASIN/ 0063562626/.

Leitl, M. (2006). Was ist ... Skunk Works? Harvard Business Manager, (12): 18. URL http://www.harvardbusinessmanager.de/heft/artikel/a-612370-druck.html. 
Lindbeck, A., and Snower, D. (2000). The Division of Labor and the Market for Organizations. IZA Discussion Papers 119, Institute for the Study of Labor (IZA). URL http://econpapers.repec.org/RePEc:iza:izadps:dp119.

Lindbeck, A., and Snower, D. (2001). Centralized bargaining and reorganized work: Are they compatible? European Economic Review, 45(10): 1851-1875. URL http://econpapers.repec.org/RePEc:eee:eecrev:v:45:y:2001:i:10:p:1851-1875.

Ludsteck, J. (2003). Comment on: "Centralized Bargaining and Reorganized Work: Are they Compatible?". MPRA Paper 30164, University Library, Munich, Germany. URL http://econpapers.repec.org/RePEc:pra:mprapa:30164.

Marglin, S. (1974). What do Bosses Do? The Origins and Functions of Hierarchy in Capitalist Production. Review of Radical Political Economics, 6: 33-66. URL http://edwardmcphail.com/dismal_science/what_do_bosses_do.pdf.

Marx, K. (1867). Capital, volume 1. Moscow: Progress Publishers. URL http://www.marxists.org/archive/marx/works/cw/volume35/. Translated from the 4th German edition by Samuel Moore and Edward Aveling.

Maynard Smith, J. (1978). The Evolution of Behavior. Scientific American, (9): $136-45$.

Milkovich, G. T., and Newman, J. M. (1999). Compensation. Boston: Irwin/McGraw-Hill, 6 edition. URL http://amazon.com/o/ASIN/0072875437/.

Mill, J. S. (2004). A System of Logic, Ratiocinative and Inductive. Kessinger Publishing, 8 edition. ISBN 9780766188747. URL http://www.laits.utexas.edu/ poltheory/mill/sol/.

Moore, J. (1992). The Firm as a Collection of Assets. European Economic Review, 36(2/3): 493-507. uRL http://econpapers.repec.org/RePEc:eee:eecrev:v:36:y:1992: i:2-3:p:493-507.

Mücke, P. (2002). Unternehmensgrenzen und Arbeitsmärkte. Marburg: Metropolis. URL http://www.metropolis-verlag.de/ Unternehmensgrenzen-und-Arbeitsmaerkte/364/book.do. 
Nelson, R. R., and Winter, S. G. (1982). An Evolutionary Theory of Economic Change. Cambridge, Mass.: Harvard University Press. URL http://amazon.com/ o/ASIN/B001G48SKS/.

Schlicht, E. (1997). Patterned Variation. The Role of Psychological Dispositions in Social and Economic Evolution. Journal of Institutional and Theoretical Economics, 153(4): 722-36. URL http://www.semverteilung.vwl.uni-muenchen.de/ mitarbeiter/es/paper/schlicht_patterned-variation.pdf.

Schlicht, E. (1998). On Custom in the Economy. Oxford: Clarendon Press. URL http://www.oxfordscholarship.com/oso/public/content/economicsfinance/ 0198292244/toc.html?q=Schlicht.

Schlicht, E. (2003). Consistency in Organization. IZA Discussion Papers 718, Institute for the Study of Labor (IZA), Schaumburg-Lippe-Strasse 5-9, 53113 Bonn, Germany. URL http://econpapers.repec.org/RePEc:iza:izadps:dp718.

Schlicht, E. (2004). Social Evolution, Corporate Culture, and Exploitation. Journal of Institutional and Theoretical Economics (JITE), 160(2). URL http://econpapers.repec.org/RePEc:mhr:jinste:urn:sici:0932-4569(200406)160: 2_232:seccae_2.0.tx_2-c.

Schlicht, E. (2008). Consistency in Organization. Journal of Institutional and Theoretical Economics (JITE), 164(4): 612-623. URL http://econpapers.repec. org/RePEc:mhr:jinste:urn:sici:0932-4569(200812)164:4_612:cio_2.0.tx_2-.

Simon, H. (1951). A Formal Theory of the Employment Relationship. Econometrica, 19(3): 293-305. URL http://stevereads.com/papers_to_read/simon_formal_ theory_of_the_employment_relationship.pdf.

Stiglitz, J. E. (1991). Symposium on Organizations and Economics. The Journal of Economic Perspectives, 5(2): pp. 15-24. ISSN 08953309. uRL http://www.jstor. org/stable/1942683.

Walsh, A. (2008). Hayekian insights into intra-firm coordination: Exploring the rule following perspective. Master's thesis, Dublin City University. URL http://doras.dcu.ie/2361/. 
Walsh, A. (2010). Two meanings of command? Command in the Instrumental Organisation versus Coercive Command. Studies in Emergent Order, 3: 28-49. URL http://docs.sieo.org/SIEO_3_2010_Walsh.pdf.

Williamson, O. E. (1980). The Organization of Work. Journal of Economic Behavior and Organization, 1: 5-38. URL http://econpapers.repec.org/RePEc: eee:jeborg:v:1:y:1980:i:1:p:5-38.

Williamson, O. E. (1985). The Economic Institutions of Capitalism. New York: Free Press. URL http://amazon.com/o/ASIN/068486374X/. 